\title{
STUDI ETNOBOTANI DAN UPAYA KONSERVASI TANAMAN YANG \\ DIGUNAKAN SEBAGAI PENGOBATAN TRADISIONAL PERAWATAN WANITA DI SUKU USING KABUPATEN BANYUWANGI
}

\author{
Norma Nur Azizah, Fuad Ardiyansyah, N.Nurchayati \\ Program Studi Biologi, Fakultas Matematika dan Ilmu Pengetahuan Alam \\ Universitas PGRI Banyuwangi \\ Email: nurma.azizah27@gmail.com
}

\begin{abstract}
ABSTRAK
Penelitian ini dilakukan untuk mengetahui tanaman-tanaman obat yang digunakan Sebagai Pengobatan Tradisional Perawatan Wanita di Suku Using Kabupaten Banyuwangi dengan jumlah responden yaitu 390 orang. Metode yang digunakan adalah metode deskriptif eksploratif dengan teknik survei lapangan dan wawancara dari narasumber yang berprofesi sebagai pembuat jamu, dukun bayi dan masyarakat suku Using. Data yang diambil meliputi data keanekaragaman tanaman obat. Bagian tanaman obat, sumber perolehan tanaman obat dan data tingkat pengetahuan masyarakat suku Using terhadap penggunaan tanaman obat sebagai perawatan wanita.Hasil penelitian yang didapat dari responden masyarakat Suku Using di Kabupaten Banyuwangi terdapat 25 spesies tanaman obat dari 10 famili yang digunakan sebagai pengobatan tradisional perawatan wanita. Famili Zingiberaceae merupakan famili yang paling banyak digunakan. Bagian-bagian tanaman yang digunakan sebagai bahan pengobatan perawatan wanita yaitu daun, rimpang, umbi, biji dan bunga. Masyarakat suku Using memperoleh tanaman obat dari kebun.
\end{abstract}

Kata kunci: Etnobotani, deskriptif ekploratif, pengobatan tradisional perawatan wanita, suku using.

\section{PENDAhuluan}

Suku Using merupakan penduduk asli Banyuwangi. Masyarakat suku Using menggunakan dan melestarikan tumbuhan obat agar tetap ada dan tumbuh.Menurut Rahayu (2006) Salah satu ciri budaya masyarakat di negara berkembang adalah masih dominannya unsur-unsur tradisional dalam kehidupan sehari-hari.

Pengetahuan masyarakat tentang pemanfaatan tanaman obat secara tradisioanal biasa disebut sebagai Etnobotani. Etnobotani dapat digunakan sebagai salah satu alat untuk mendokumentasikan pengetahuan masyarakat tradisional.Masyarakat suku Using memiliki adat istiadat yang beragam dalam memanfaatkan tumbuhan. Pemanfaatan tumbuhan dalam keperluan sehari-hari tidak hanya sebagai bahan 
pangan, pakaian, dan tempat tinggal, tetapi juga untuk pengobatan, salah satunya kecantikan atau perawatan tubuh. Masyarakat suku Using masih melibatkan tanaman obat sebagai pengobatan tradisional khususnya perawatan wanita dengan adanya masyarakat yaug menggunakan tanaman obat sebagai obat herbal dan jamu membuktikan tanamaan obat masih diminati dan di percayai memiliki khasiat khusus untuk menyembuhkan suatu penyakit, maka dari itu topik ini dipilih karena perawatan wanita memiliki unsur lebih komplek yang meliputi kesehatan reproduksi, kehamilan, kelahiran, setelah melahirkan atau menyusui, kosmetika dan perawatan sehari-hari.

Data dan informasi tentang pemanfaatan dan pengetahuan tanaman obat suku Using belum tersedia dan terdokumetasi. Masyarakat umumnya menurunkan pengetahuan dari mulut ke mulut atau tradisi lisan. Hal tersebut mendatangkan kekhawatiranakan punahnya pengetahuan tradisional dalam pemanfaatan tanaman obat. Maka dari itu perlu adanya publikasi dan informasi mengenai hal ini sangat diperlukan guna mendasari upaya pelestarian pemanfaatan dan pengembangan usaha pemanfaatan tanaman obat (Zuhud dan Haryanto 1990). Studi tentang tumbuhan obat juga semakin strategis ditengah-tengah semakin mahalnya biaya obat dan pengobatan (Hakim, 2014).

\section{METODE PENELITIAN}

Penelitian bab ini menggunakan jenis deskriptif eksploratif dengan teknik survei lapangan dan wawancara dari narasumber dengan profesi yang berbeda-beda. Data yang diambil meliputi data keanekaragaman tumbuhan obat. Komposisi ramuan obat, tumbuhan yang digunakan masyarakat Using tentang tanaman obat dan data tingkat pengetahuan pemanfaatan tanaman obat oleh masyarakat suku Using di Banyuwangi.

Penelitian ini dilaksanakan di lima kecamatan yang meliputi kecamatan Glagah, Giri, Singojuru, Kabat, Rogojampi pada bulan maret sampai Juli 2018. Penelitian ini menggunakan metode deskriptif kualitatif dengan teknik survei lapangan dan 
wawancara dari narasumber dengan profesi yang berbeda-beda. Data yang diambil meliputi data keanekaragaman tumbuhan obat. komposisi ramuan obat. tumbuhan yang digunakan masyarakat Using tentang tanaman obat dan data tingkat pengetahuan masyarakat suku Using terhadap pengunaan tumbuhan obat. Alat yang digunakan pada penelitian Etnobotani tanaman bemanfaat pada suku Using ini meliputi kamera, alat perekam dan alat tulis. Bahan yang digunakan semua tumbuhan obat bermanfaat yang biasa digunakan oleh suku Using di wilayah kecamatan terpilih meliputi Glagah, Giri, Kabat, Singojuru, Rogojampi.

Analisa data dari penelitin ini menggunakan teknik analisis deskriptif kualitatif. Analisis yang digunakan merupakan analisis isi (content analysis) berdasarkan data pengetahuan responden terhadap tumbuhan yang digunakan oleh masyarakat suku Using di wilayah yang terpilih. Kualitatif data tersebut diperoleh dari wawancara pada masyarakat. Data kualitatif berupa deskripsi tentang nama spesies, famili, habitus, bagian tumbuhan yang digunakan serta pengelompokan manfaat tumbuhan dalam beberapa kegunaan. Tumbuhan bermanfaat untuk obat diperoleh data kualitatif terkait jenis tumbuhan, manfaat, cara penggunaan dan proses pembuatan. Sedangkan data hasil wawancara berupa data presentase jenis tanaman, bagian dari organ yang digunakan, cara mendapatkan dan nilai manfaat dari tanaman yang dimanfaatkan oleh masyarakat berbentuk diagram distribusi frekuensi relatif dan dikalkulasi dalam bentuk persentase berdasarkan rumus berikut:

a. Persentase jenis tanaman

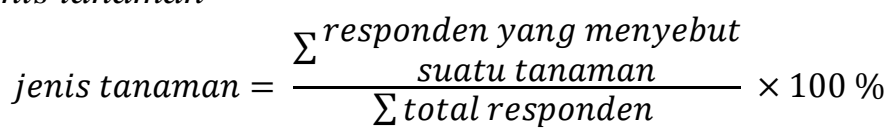

b. Persentase bagian tanaman yang digunakan

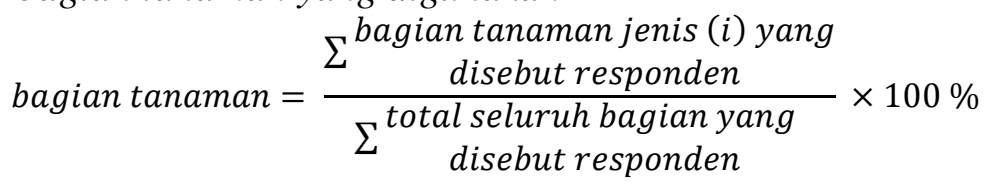


c. Persentase sumber perolehan

$$
\text { sumber perolehan jenis }(i)=\frac{\sum_{\text {sumber perolehan jenis tanaman }}^{\text {responden yang menyebut }}}{\sum_{\text {total seluruh sumber perolehan }}^{\text {yang disebut responden }}} \times 100 \%
$$

\section{HASIL DAN PEMBAHASAN}

\section{a. Keragaman Jenis Tanaman Obat Perawatan Wanita}

Berdasarkan hasil wawancara dengan 390 responden yang terdiri dari pembuat jamu, dukun bayi, ketua adat dan masyarakat umum yang mengerti banyak tentang tanaman obat, diketahui terdapat 25 jenis tanaman yang digunakan sebagai pengobatan tradisional perawatan wanita sebagai bahan pengobatan untuk masyarakat Suku Using di Kabupaten Banyuwangi. Jenis-jenis tanaman yang digunakan sebagai bahan pengobatan tersebut terekam dalam tabel 1. di bawah ini.

\section{Tabel 1 Spesies tanaman yang digunakan untuk Pengobatan Tradisional} Perawatan Wanita

\begin{tabular}{|c|c|c|c|c|c|c|}
\hline \multirow[b]{2}{*}{ No } & \multicolumn{4}{|c|}{ Nama Tumbuhan } & \multirow{2}{*}{$\begin{array}{l}\text { Bagian } \\
\text { yang di } \\
\text { gunakan }\end{array}$} & \multirow{2}{*}{ Kegunaan } \\
\hline & Umum & Lokal & Ilmiah & Famili & & \\
\hline 1 & 2 & 3 & 4 & 5 & 6 & 7 \\
\hline 1 & Pepaya & Kates & $\begin{array}{l}\text { Carica } \\
\text { papaya }\end{array}$ & Caricaceae & Daun & $\begin{array}{l}\text { memperlancar } \\
\text { asi }\end{array}$ \\
\hline 2 & Lempuyang & Lempuyang & $\begin{array}{l}\text { Zingiber } \\
\text { aromaticum }\end{array}$ & Zingiberaceae & Rimpang & $\begin{array}{l}\text { mengatasi } \\
\text { keputihan, untuk } \\
\text { ibu menyusui }\end{array}$ \\
\hline 3 & $\begin{array}{l}\text { Kunyit } \\
\text { kunig }\end{array}$ & $\begin{array}{l}\text { Kunir } \\
\text { kuning }\end{array}$ & $\begin{array}{l}\text { Curcuma } \\
\text { longa }\end{array}$ & Zingiberaceae & Rimpang & $\begin{array}{l}\text { mengatasi } \\
\text { keputihan, untuk } \\
\text { ibu menyusui, } \\
\text { nyeri haid, } \\
\text { empo-empon, } \\
\text { setelah } \\
\text { melahirkan }\end{array}$ \\
\hline 4 & Sembukan & Sembuan & $\begin{array}{l}\text { Paederia } \\
\text { foetida }\end{array}$ & Rubiaceae & Daun & $\begin{array}{l}\text { mengatasi } \\
\text { keputihan }\end{array}$ \\
\hline 5 & Lampes & Lampes & $\begin{array}{l}\text { Ocinum } \\
\text { sanchum }\end{array}$ & Lamiaceae & Daun & $\begin{array}{l}\text { mengatasi } \\
\text { keputihan }\end{array}$ \\
\hline 6 & Asem & Sinom & $\begin{array}{l}\text { Tamarindus } \\
\text { indica }\end{array}$ & Fabaceae & Daun & $\begin{array}{l}\text { mengatasi } \\
\text { keputihan, nyeri } \\
\text { haid }\end{array}$ \\
\hline 7 & Beluntas & Beluntas & $\begin{array}{l}\text { Plucea } \\
\text { indica }\end{array}$ & asteraceae & Daun & $\begin{array}{l}\text { mengatasi } \\
\text { keputihan }\end{array}$ \\
\hline
\end{tabular}


BIOSENSE Vol. 2 No. 2, Desember 2019

ISSN : $2622-6286$

\begin{tabular}{|c|c|c|c|c|c|c|}
\hline 1 & 2 & 3 & 4 & 5 & 6 & 7 \\
\hline 8 & Kunci & Kunci & $\begin{array}{l}\text { Boesenbergi } \\
\text { a rotunda }\end{array}$ & Zingiberaceae & Rimpang & $\begin{array}{l}\text { empon-empon, } \\
\text { setelah } \\
\text { melahirkan }\end{array}$ \\
\hline 9 & Lengkuas & Laos & $\begin{array}{l}\text { Alpina } \\
\text { galangal }\end{array}$ & Zingiberaceae & Rimpang & $\begin{array}{l}\text { empon-empon, } \\
\text { setelah } \\
\text { melahirkan }\end{array}$ \\
\hline 10 & Temulawak & Temulawak & $\begin{array}{l}\text { Curcuma } \\
\text { xanthorrhiza }\end{array}$ & Zingiberaceae & Rimpang & $\begin{array}{l}\text { untuk ibu } \\
\text { menyusui, } \\
\text { setelah } \\
\text { melahirkan }\end{array}$ \\
\hline 11 & Temu ireng & Temu ireng & $\begin{array}{l}\text { Curcuma } \\
\text { aeruginosa }\end{array}$ & Zingiberaceae & Rimpang & $\begin{array}{l}\text { setelah } \\
\text { melahirkan }\end{array}$ \\
\hline 12 & Sirih & Suruh & Piper betle & Piperaceae & Daun & $\begin{array}{l}\text { setelah } \\
\text { melahirkan, } \\
\text { mengatasi } \\
\text { keputihan }\end{array}$ \\
\hline 13 & Waru & Waru & $\begin{array}{l}\text { Hibiscus } \\
\text { tiliacum }\end{array}$ & Maluaceae & Daun & $\begin{array}{l}\text { sebelum } \\
\text { melahirkan }\end{array}$ \\
\hline 14 & Pisang & Pisang & $\begin{array}{l}\text { Musa } \\
\text { paradisiaca }\end{array}$ & Musaceae & Bunga & $\begin{array}{l}\text { memperlancar } \\
\text { asi }\end{array}$ \\
\hline 15 & Polo & Polo & $\begin{array}{l}\text { Myristica } \\
\text { fragrans }\end{array}$ & Myristicaceae & Biji & $\begin{array}{l}\text { mengatasi } \\
\text { keputihan }\end{array}$ \\
\hline 16 & temu putih & Temu putih & $\begin{array}{l}\text { Curcuma } \\
\text { zedoria }\end{array}$ & Zingiberaceae & Rimpang & $\begin{array}{l}\text { setelah } \\
\text { melahirkan } \\
\text { tanpa jahit } \\
\end{array}$ \\
\hline 17 & Temu poh & Temu poh & $\begin{array}{l}\text { Curcuma } \\
\text { mangga }\end{array}$ & Zingiberaceae & Rimpang & $\begin{array}{l}\text { setelah } \\
\text { melahirkan } \\
\text { tanpa jahit }\end{array}$ \\
\hline 18 & Wadung & Wadung & $\begin{array}{l}\text { Dialium } \\
\text { ovoideum } \\
\text { thwaites }\end{array}$ & Fabaceae & Daun & $\begin{array}{l}\text { setelah } \\
\text { melahirkan } \\
\text { tanpa jahit }\end{array}$ \\
\hline 19 & Jahe & Jahe & $\begin{array}{l}\text { Zingiber } \\
\text { officinale }\end{array}$ & Zingiberaceae & Rimpang & $\begin{array}{l}\text { setelah } \\
\text { melahirkan }\end{array}$ \\
\hline 20 & Jambu & Jambu & $\begin{array}{l}\text { Psidium } \\
\text { guajava }\end{array}$ & Myrtaceae & Daun & Masker \\
\hline 21 & Bengkuang & Bengkuang & $\begin{array}{l}\text { Pachyrhizus } \\
\text { erosus }\end{array}$ & Fabaceae & Buah & Masker \\
\hline 22 & Kencur & Kencur & $\begin{array}{l}\text { Kaempferia } \\
\text { galangal }\end{array}$ & Zingiberaceae & Rimpang & $\begin{array}{l}\text { Mengatasi } \\
\text { keputihan }\end{array}$ \\
\hline 23 & Bangle & Bangle & $\begin{array}{l}\text { Zingiber } \\
\text { cassumunar } \\
\text { Roxb. }\end{array}$ & Zingiberaceae & Rimpang & $\begin{array}{l}\text { Setelah } \\
\text { melahirkan }\end{array}$ \\
\hline 24 & Kelapa & Kelopo & $\begin{array}{l}\text { Cocos } \\
\text { nucifera }\end{array}$ & Palmae & Buah & $\begin{array}{l}\text { Mengatasi } \\
\text { keputihan }\end{array}$ \\
\hline 25 & Kunyit putih & Kunir putih & $\begin{array}{l}\text { Curcuma } \\
\text { zedoaria }\end{array}$ & Zingiberaceae & Rimpang & $\begin{array}{l}\text { Setelah } \\
\text { melahirkan }\end{array}$ \\
\hline
\end{tabular}

Studi Etnobotani Dan Upaya Konservasi Tanaman Yang Digunakan Sebagai Pengobatan Tradisional Perawatan Wanita Di Suku Using Kabupaten Banyuwangi 
Berdasarkan tabel diatas terdapat 25 jenis tanaman yang digunakan sebagai bahan pengobatan tradisional perawatan wanita di Suku Using Kabupaten Banyuwangi. Spesies-spesies tanaman obat yang digunakan dikelompokkan dalam 10 familia yang meliputi Zingiberaceae, Fabaceae, Myristicaceae, Caricaceae, Rubiaceae, Lamiaceae, Asteraceae, Piperaceae, Malvaceae, Palmae dan Musaceae. Familia Zingiberaceae merupakan famili dengan jumlah spesies terbanyak, diantaranya Curcuma domestica(kunyit) (Winarto, 2004), Zingiber aromaticum (lempuyang), Boesenbergia rotunda L (kunci), Alpina galanga (lengkuas), Curcuma xanthorrhiza (temulawak), Curcuma aeruginosa (temu ireng), Curcuma zedoria (temu putih), Curcuma mangga (temu poh), Zingiber officinale (jahe), Kaempferia galanga (kencur), Zingiber cassumunar Roxb (bangle) dan Curcuma zedoaria (kunyit putih).. Masyarakat suku Using banyak menggunakan tanaman obat dari famili Zingiberaceae karena Menurut Gembong (2002) suku tanaman ini adalah tumbuhan herba parenial dengan rhizome yang mengandung minyak menguap hingga berbau aromatik. Hasil penelitian yang pernah dilakukan oleh Sinaga (2011), suku Zingiberaceae banyak digunakan untuk obat-obatan dan telah digunakan ratusan tahun yang lalu karena rimpang dari Zingiberaceae mengandung Limonen, Eugenol, dan Geraniol. Ketiga komponen tersebut bersifat antiseptik sehingga dapat dimanfaatkan sebagai bahan desinfektan (Agusta, 2002).

Hasil dari penelitian Etnobotani pada masyarakat Suku Using didapat data tentang kategori pemanfaatan tanaman obat perawatan wanita. Kategori pemanfaatan tanaman obat perawatan wanita dapat dilihat pada tabel 2 .

Tabel 2. Kategori Pemanfaatan Tanaman Obat Perawatan Wanita

\begin{tabular}{ccc}
\hline No & Jenis Perawatan Pada Wanita & Nama Spesies Tanaman Obat Yang Dimanfaatakan \\
\hline 1 & 2 & 3 \\
\hline $1 \quad$ Memperlancar asi & $\begin{array}{l}\text { pepaya (Carica papaya), pisang (Musa paradisiaca), } \\
\text { kunyit (Curcuma longa), lempuyang (Zingiber } \\
\text { aromaticum), temulawak (Curcuma xanthorrhiza) }\end{array}$ \\
\hline
\end{tabular}




\begin{tabular}{|c|c|c|}
\hline 1 & 2 & 3 \\
\hline 2 & Mengatasi Keputihan & $\begin{array}{l}\text { lempuyang (Zingiber aromaticum), kunyit (Curcuma } \\
\text { longa), beluntas (Plucea indica), asam jawa } \\
\text { (Tamarindus indica), sembukan (Paederia foetida), } \\
\text { lampes (Ocinum sanchum), pala (Myristica fragrans), } \\
\text { Sirih (Piper betle, kelapa (Cocos nucifera), kunci } \\
\text { (Boesenbergia rotunda) }\end{array}$ \\
\hline 3 & Sebelum Melahirkan & waru (Hibiscus tiiacum) \\
\hline 4 & Setelah Melahirkan & $\begin{array}{l}\text { temu ireng (Curcuma aeruginosa), temulawak } \\
\text { (Curcuma xanthorrhiza), temu putih (Curcuma } \\
\text { zedoria), temu poh (Curcuma mangga), jahe (Zingiber } \\
\text { officinale, kunci (Boesenbergia rotunda), lengkuas } \\
\text { (Alpina galanga), bangle (Zingiber cassumunar Roxb) }\end{array}$ \\
\hline 5 & Nyeri Haid & $\begin{array}{l}\text { kunyit (Curcuma longa), asam jawa } \\
\text { (Tamarindus indica) }\end{array}$ \\
\hline 6 & Masker & $\begin{array}{l}\text { bengkuang (Pachyrhizus erosus), jambu (Psidium } \\
\text { guajava) }\end{array}$ \\
\hline 7 & Menyingsetkan badan & kunci (Boesenbergia rotunda) \\
\hline
\end{tabular}

Berdasarkan tabel diatas didapat 7 jenis perawatan wanita yang ada di Suku Using Kabupaten Banyuwangi yang meliputi mengatasi keputihan, nyeri haid, melancarkan asi, perawatan setelah melahirkan dan sebelum melahirkan, menyingsetkan badan dan digunakan untuk perwatan kecantikan seperti masker.

b. Persentase Pengetahuan Masyarakat Suku Using Terhadap Tanaman Perawatan Wanita

Berdasarkan wawancara dengan responden tentang pengetahuan masyarakat terhadap jenis tanaman sebagai bahan obat terangkum dalam tabel 3 sebagai berikut:

Tabel 3. Persentase Pengetahuan masyarakat tentang jenis tanaman yang digunakan sebagai bahan obat

\begin{tabular}{|c|c|c|c|c|c|}
\hline \multirow{2}{*}{ No } & \multicolumn{4}{|c|}{ Nama Tumbuhan } & \multirow{2}{*}{$\begin{array}{c}\text { Pengetahuan } \\
\text { masyarakat }\end{array}$} \\
\hline & Umum & Lokal & Ilmiah & Famili & \\
\hline 1 & 2 & 3 & 4 & 5 & 6 \\
\hline 1 & Pepaya & Kates & Carica papaya & Caricaceae & $3 \%$ \\
\hline 2 & Lempuyang & Lempuyang & Zingiber aromaticum & Zingiberaceae & $6 \%$ \\
\hline 3 & Kunyit & Kunir & Curcuma longa & Zingiberaceae & $12 \%$ \\
\hline
\end{tabular}


BIOSENSE Vol. 2 No. 2, Desember 2019

ISSN : $2622-6286$

\begin{tabular}{|c|c|c|c|c|c|}
\hline & kuning & kuning & & & \\
\hline 4 & Sembukan & Sembuan & Paederia foetida & Rubiaceae & $2 \%$ \\
\hline 5 & Lampes & Lampes & Ocinum sanchum & Lamiaceae & $1 \%$ \\
\hline 6 & Asam jawa & Sinom & Tamarindus indica & Fabaceae & $9 \%$ \\
\hline 7 & Beluntas & Beluntas & Plucea indica & asteraceae & $3 \%$ \\
\hline 8 & Kunci & Kunci & Boesenbergia rotunda & Zingiberaceae & $8 \%$ \\
\hline 9 & Lengkuas & Laos & Alpina galangal & Zingiberaceae & $7 \%$ \\
\hline 10 & Temulawak & Temulawak & Curcuma xanthorrhiza & Zingiberaceae & $8 \%$ \\
\hline 11 & Temu ireng & Temu ireng & Curcuma aeruginosa & Zingiberaceae & $3 \%$ \\
\hline 12 & Sirih & Suruh & Piper betle & Piperaceae & $4 \%$ \\
\hline 13 & Waru & Waru & Hibiscus tiliacum & Maluaceae & $1 \%$ \\
\hline 14 & Pisang & Pisang & Musa paradisiaca & Musaceae & $3 \%$ \\
\hline 15 & Polo & Polo & Myristica fragrans & Myristicaceae & $2 \%$ \\
\hline 16 & temu putih & Temu putih & Curcuma zedoria & Zingiberaceae & $3 \%$ \\
\hline 17 & Temu poh & Temu poh & Curcuma mangga & Zingiberaceae & $2 \%$ \\
\hline 18 & Wadung & Wadung & $\begin{array}{l}\text { Dialium ovoideum } \\
\text { thwaites }\end{array}$ & Fabaceae & $1 \%$ \\
\hline 19 & Jahe & Jahe & Zingiber officinale & Zingiberaceae & $8 \%$ \\
\hline 20 & Jambu & Jambu & Psidium guajava & Myrtaceae & $1 \%$ \\
\hline 21 & Bengkuang & Bengkuang & Pachyrhizus erosus & Fabaceae & $1 \%$ \\
\hline 22 & kencur & Kencur & Kaempferia galanga & Zingiberaceae & $3 \%$ \\
\hline 23 & bangle & Bangle & $\begin{array}{l}\text { Zingiber cassumunar } \\
\text { Roxb. }\end{array}$ & Zingiberaceae & $2 \%$ \\
\hline 24 & kelapa & Kelopo & Cocos nucifera & Palmae & $4 \%$ \\
\hline 25 & $\begin{array}{l}\text { Kunyit } \\
\text { putih }\end{array}$ & Kunir putih & Curcuma zedoaria & Zingiberaceae & $2 \%$ \\
\hline
\end{tabular}




\section{Persentase Pengetahuan Tanaman Obat}

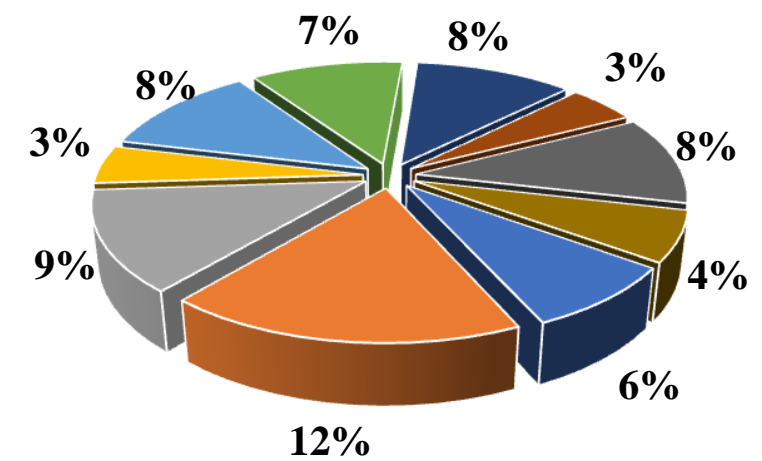

\begin{tabular}{|c|c|c|c|}
\hline $\begin{array}{l}\text { lempuyang } \\
\text { lengkuas }\end{array}$ & $\begin{array}{l}\text { " kunyit } \\
\text { - temulawak }\end{array}$ & $\begin{array}{l}\text { asam jawa } \\
\text { temu ireng }\end{array}$ & $\begin{array}{l}\text { beluntas } \\
\text { jahe }\end{array}$ \\
\hline
\end{tabular}

Gambar 1. Persentase 10 teratas tentang pengetahuan masyarakat terhadap pemanfaatan jenis-jenis tanaman sebagai bahan obat

Berdasarkan gambar diatas terdapat 10 persentase jenis tanaman yang meliputi kunyit, asem, jahe, kunci, temulawak, lempuyang, beluntas lengkuas, sirih dan temu ireng jenis tanman yang paling banyak diketahui masyarakat Suku Using yaitu kunyit (Curcuma longa) sebesar 12\%. Jenis tanaman lain yang sering disebut responden adalah asem (Tamarindus indica) sebesar 9\%, kunci (Boesenberia rotunda L) sebesar 8\%. Lengkuas (Alpina galangal) sebesar 7\%, temulawak (Curcuma xanthorrhiza) sebesar 8\%, jahe (Zingiber officinale) sebesar 8\%, lempuyang (Zingiber aromaticum) sebesar 6\%, sirih (Piper betle) sebesar 4\%,temu ireng (Curcuma aeruginosa) sebesar 3\%, dan beluntas (Plucea indica) sebesar 3\%.Menurut Said, (2007) kunyit memiliki efek farmakologis seperti, melancarkan darah, menghilangkan sumbatan peluruh haid, antiradang (anti-inflamasi), mempermudah persalinan dan antibakteri. sehingga masyarakat suku Using tetap menggunakan kunyit sebagai bahan ramuan pengobatan perawatan wanita sampai saat ini yang sering dikenal sebagai empon-emponPemanfaatan Bagian (Organ) Tanaman yang digunakan untuk Pengobatan Tradisional Pertawatan Wanita 
Hasil dari penelitian yang didapat dari masyarakat Suku Using di Kabupaten Banyuwangi terdapat bemacam-macam pemanfaatan bagian tanaman yang digunakan untuk pengobatan tradisional perawatan wanita. Bagian-bagian (Organ) tanaman yang digunakan untuk pengobatan tradisional perawatan wanita tersebut terekam dalam Tabel 4 di bawah ini

\section{Tabel 4 Bagian-Bagian (Organ) Tanaman yang digunakan untuk Pengobatan Tradisional Perawatan Wanita}

\begin{tabular}{|c|c|c|c|c|c|}
\hline \multirow{2}{*}{ No } & \multicolumn{4}{|c|}{ Nama Tumbuhan } & \multirow{2}{*}{$\begin{array}{c}\text { Bagian yang } \\
\text { digunakan }\end{array}$} \\
\hline & Umum & Lokal & Ilmiah & Famili & \\
\hline 1 & 2 & 3 & 4 & 5 & 6 \\
\hline 1 & Pepaya & Kates & Carica papaya & Caricaceae & Daun \\
\hline 2 & Lempuyang & Lempuyang & Zingiber aromaticum & Zingiberaceae & Rimpang \\
\hline 3 & $\begin{array}{l}\text { Kunyit } \\
\text { kuning }\end{array}$ & $\begin{array}{l}\text { Kunir } \\
\text { kuning }\end{array}$ & Curcuma longa & Zingiberaceae & Rimpang \\
\hline 4 & Sembukan & Sembuan & Paederia foetida & Rubiaceae & Daun \\
\hline 5 & Lampes & Lampes & Ocinum sanchum & Lamiaceae & Daun \\
\hline 6 & Asam jawa & Sinom & Tamarindus indica & Fabaceae & Daun \\
\hline 7 & Beluntas & Beluntas & Plucea indica & asteraceae & Daun \\
\hline 8 & Kunci & kunci & Boesenbergia rotunda & Zingiberaceae & Rimpang \\
\hline 9 & Lengkuas & Laos & Alpina galangal & Zingiberaceae & Rimpang \\
\hline 10 & Temulawak & Temulawak & Curcuma xanthorrhiza & Zingiberaceae & Rimpang \\
\hline 11 & Temu hitam & Temu ireng & Curcuma aeruginosa & Zingiberaceae & Rimpang \\
\hline 12 & Sirih & Suruh & Piper betle & Piperaceae & Daun \\
\hline 13 & Waru & Waru & Hibiscus tiliacum & Maluaceae & Daun \\
\hline 14 & Pisang & Pisang & Musa paradisiaca & Musaceae & Bunga \\
\hline 15 & Polo & Polo & Myristica fragrans & Myristicaceae & Biji \\
\hline 16 & temu putih & Temu putih & Curcuma zedoria & Zingiberaceae & Rimpang \\
\hline 17 & Temu poh & Temu poh & Curcuma mangga & Zingiberaceae & Rimpang \\
\hline 18 & Wadung & wadung & $\begin{array}{l}\text { Dialium ovoideum } \\
\text { thwaites }\end{array}$ & Fabaceae & Daun \\
\hline 19 & Jahe & Jahe & Zingiber officinale & Zingiberaceae & Rimpang \\
\hline 20 & Jambu & Jambu & Psidium guajava & Myrtaceae & Daun \\
\hline 21 & Bengkuang & Bengkuang & Pachyrhizus erosus & Fabaceae & Umbi \\
\hline 22 & kencur & kencur & Kaempferia galangal & Zingiberaceae & Rimpang \\
\hline 23 & bangle & bangle & $\begin{array}{l}\text { Zingiber cassumunar } \\
\text { Roxb. }\end{array}$ & Zingiberaceae & Rimpang \\
\hline 24 & kelapa & kelopo & Cocos nucifera & Palmae & Buah \\
\hline 25 & $\begin{array}{l}\text { Kunyit } \\
\text { putih }\end{array}$ & Kunir putih & Curcuma zedoaria & Zingiberaceae & Rimpang \\
\hline
\end{tabular}


Dari wawancara dengan 390 responden tentang bagian-bagian tanaman yang digunakan untuk pengobatan tradisional perawatan wanita di Suku Using Kabupaten Banyuwangi terangkum dalam gambar 4.2 sebagai berikut :

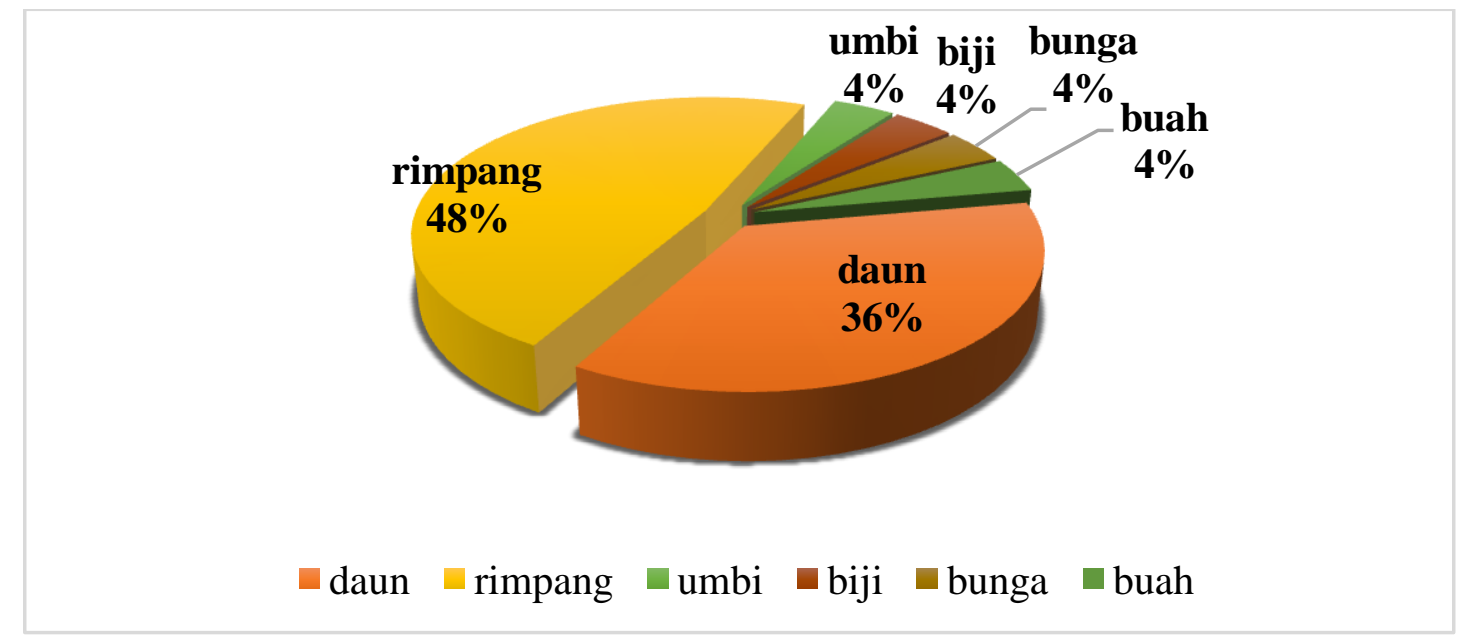

Gambar 2. Persentase bagian-bagian (organ) tanaman yang digunakan untuk Pengobatan Tradisional Perawatan Wanita

Berdasarkan hasil penelitian yang didapat dari responden masyarakat Suku Using di Kabupaten Banyuwangi terdapat bermacam-macam bagian tanaman obat yang digunakan diantaranya bagian rimpang sebesar $48 \%$, daun sebesar $36 \%$, umbi sebesar $4 \%$, biji sebesar $4 \%$, bunga sebesar $4 \%$ dan biji sebesar $4 \%$. Pemanfaatan bagian tanaman obat paling banyak digunakan pada bagian rimpang.Menurut Hariana (2007) tanaman berakar rimpang memiliki senyawa aktif seperti flavonoid, saponin dan minyak atsiri yang terdiri dari kamfen, sineol, metal sinamat, galangan, galangin dan alpine. Kandungan-kandungan ini memiliki banyak manfaat untuk digunakan sebagai obat diantaranya melancarkan peredaran darah dan menghambat pertumbuhan mikroba. Bagian tanaman obat yang biasa digunakan berupa akar, kulit batang, kayu, daun, bunga atau bijinya (Adfa. 2005) 
c. Sumber Perolehan Tanaman yang digunakan untuk Pengobatan Tradisional Perawatan Wanita

Hasil penelitian yang telah dilakukan terdapat berbagai macam sumber perolehan tanaman obat di Suku Using Kabupaten Banyuwangi yang terekam dalam Tabel 5. sebagai berikut :

\section{Tabel 5. Sumber Perolehan Tanaman yang digunakan untuk Pengobatan Tradisional Perawatan Wanita}

\begin{tabular}{|c|c|c|c|c|c|}
\hline \multirow{2}{*}{ No } & \multicolumn{4}{|c|}{ Nama Tumbuhan } & \multirow{2}{*}{$\begin{array}{l}\text { Bagian yang } \\
\text { digunakan }\end{array}$} \\
\hline & Umum & Lokal & Ilmiah & Famili & \\
\hline 1 & 2 & 3 & 4 & 5 & 6 \\
\hline 1 & Pepaya & Kates & Carica papaya & Caricaceae & $\begin{array}{l}\text { Pekarangan } \\
\text { halam rumah }\end{array}$ \\
\hline 2 & Lempuyang & Lempuyang & Zingiber aromaticum & Zingiberaceae & membeli \\
\hline 3 & $\begin{array}{l}\text { Kunyit } \\
\text { kuning }\end{array}$ & $\begin{array}{l}\text { Kunir } \\
\text { kuning }\end{array}$ & Curcuma longa & Zingiberaceae & $\begin{array}{l}\text { Pekarangan } \\
\text { halaman rumah }\end{array}$ \\
\hline 4 & Sembukan & Sembuan & Paederia foetida & Rubiaceae & Kebun \\
\hline 5 & Lampes & Lampes & Ocinum sanchum & Lamiaceae & Kebun \\
\hline 6 & Asam jawa & Sinom & Tamarindus indica & Fabaceae & Kebun \\
\hline 7 & Beluntas & Beluntas & Plucea indica & asteraceae & Kebun \\
\hline 8 & Kunci & kunci & Boesenbergia rotunda & Zingiberaceae & Membeli \\
\hline 9 & Lengkuas & Laos & Alpina galangal & Zingiberaceae & Membeli \\
\hline 10 & Temulawak & Temulawak & Curcuma xanthorrhiza & Zingiberaceae & Membeli \\
\hline 11 & Temu hitam & Temu ireng & Curcuma aeruginosa & Zingiberaceae & Kebun \\
\hline 12 & Sirih & Suruh & Piper betle & Piperaceae & $\begin{array}{l}\text { Pekarangan } \\
\text { halaman rumah }\end{array}$ \\
\hline 13 & Waru & Waru & Hibiscus tiliacum & Maluaceae & Kebun \\
\hline 14 & Pisang & Pisang & Musa paradisiaca & Musaceae & Kebun \\
\hline 15 & Polo & Polo & Myristica fragrans & Myristicaceae & Membeli \\
\hline 16 & temu putih & Temu putih & Curcuma zedoria & Zingiberaceae & Kebun \\
\hline 17 & Temu poh & Temu poh & Curcuma mangga & Zingiberaceae & Kebun \\
\hline 18 & Wadung & wadung & $\begin{array}{l}\text { Dialium ovoideum } \\
\text { thwaites }\end{array}$ & Fabaceae & Kebun \\
\hline 19 & Jahe & Jahe & Zingiber officinale & Zingiberaceae & $\begin{array}{l}\text { Pekarangan } \\
\text { halaman rumah }\end{array}$ \\
\hline 20 & Jambu & Jambu & Psidium guajava & Myrtaceae & $\begin{array}{l}\text { Pekarangan } \\
\text { halaman rumah }\end{array}$ \\
\hline 21 & Bengkuang & Bengkuang & Pachyrhizus erosus & Fabaceae & Membeli \\
\hline 22 & kencur & kencur & Kaempferia galanga & Zingiberaceae & Membeli \\
\hline 23 & bangle & bangle & $\begin{array}{l}\text { Zingiber cassumunar } \\
\text { Roxb. }\end{array}$ & Zingiberaceae & Kebun \\
\hline 24 & kelapa & kelopo & Cocos nucifera & Palmae & Kebun \\
\hline 25 & $\begin{array}{l}\text { Kunyit } \\
\text { putih }\end{array}$ & Kunir putih & Curcuma zedoaria & Zingiberaceae & Membeli \\
\hline
\end{tabular}




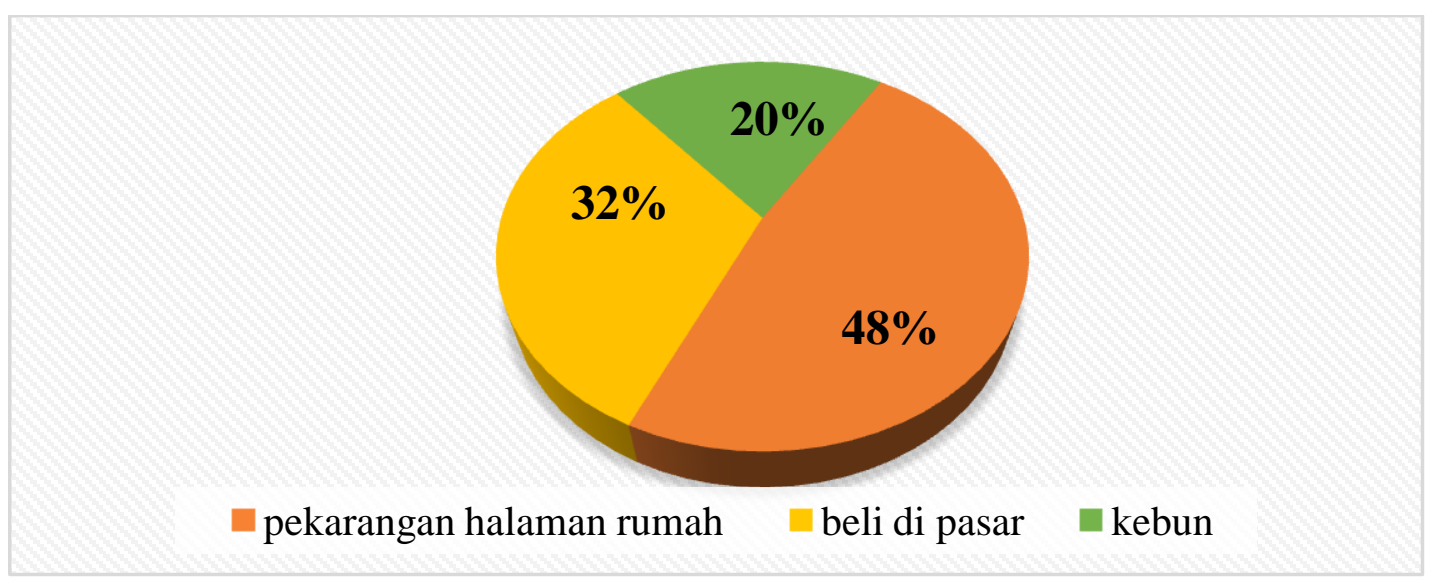

Gambar 3. Persentase sumber perolehan tanaman yang digunakan untuk pengobatan tradisional perawatan wanita

Berdasarkan gambar 4.3 tanaman obat yang paling banyak diperoleh dari kebun sebesar $48 \%$. Sedangkan tanaman obat lain masing-masing 32\% dari membeli di pasar dan $20 \%$ didapat di pekarangan halaman rumah..

\section{KESIMPULAN DAN SARAN}

\subsection{Kesimpulan}

Berdasarkan penelitian yang telah dilakukan terdapat 25 spesies tumbuhan dan terbagi menjadi 10 famili yang digunakan sebagai bahan atau ramuan untuk pengobatan tradisional perawatan wanita di Suku Using Kabupaten Banyuwangi. Bagian-bagian tanaman yang digunakan sebagai bahan pengobatan perawatan wanita yaitu daun, rimpang, umbi, biji dan bunga. Bagian yang paling banyak dimanfaatkan yaitu rimpang dengan persentase sebesar 48\%. Bahan-bahan tanaman ini dapat dijadikan sebagai obat perawatan wanita seperti nyeri haid, mengatasi keputihan, melancarkan asi, perawatan setelah melahirkan dan sebelum melahirkan. Spesies yang paling dominan digunakan sebagai bahan pengobatan tradisional wanita yaitu kunyit dan familia yang paling sering digunakan yaitu Zingiberaceae. 
Pengetahuan masyarakat Suku Using mengetahui tanaman obat secara turun temurun dan berdasarkan pengalaman. Dari 25 jenis tanaman yang paling banyak diketahui masyarakat Suku Using yaitu kunyit (Curcuma longa) sebesar 12\%. Upaya konservasi yang dilakukan masyarakat yaitu dengan menanam tanaman di pekarangan halaman rumah sebesar $20 \%$ dan di kebun sebesar $48 \%$. Hal ini membuktikan bahwa masyarakat Suku Osing sudah melakukan upaya konservasi dengan cara menanam tanaman obat di kebun dan pekarangan halaman rumah.

\subsection{Saran}

Berdasarkan kesimpulan diatas tentang pemanfaatan tanaman obat yang sangat beragam di suku Using, peneliti menyarankan agar masyarakat suku Using tetap melestarikan dan menggunakan tanaman obat sebagai bahan ramuan pengobatan tradisional perwatan wanita. Kedepannya penulis akan lebih fokus dan detail saat penelitian dan menjelaskan tentang skripsi di atas dengan sumber-sumber yang lebih banyak yang tentunya dapat di pertanggung jawabkan. Kepada peneliti selanjutnya disarankan untuk menambah lokasi atau daerah lain, apakah ada perbedaan pemanfaatan tanaman obat yang ada di suku Using Kabupaten Banyuwangi.

\section{REFERENSI}

Adfa, M. 2005. Study Senyawa Flafonoid Dan Uji Brine Shrimp Beberapa Tumbuhan Obat Tradisional Suku Serawai Di Provinsi Bengkulu. Jurnal Gradien Vol. 1. No 1 Januari 2005 : 43-50

Ahmad, Said. 2007. Khasiat dan manfaat kunyit. Jakarta :Sinar Wadja Lestari. Agusta, 2002. Aromaterapi, Cara Sehat Dengan Wewangian Alami.Jakarta : Penebar Swadaya.

Gembong, Tjitrosoepomo. 2002. Taksonomi Tumbuhan (spermatopyta). Yogyakarta : Gajah MadaUniversity Press.

Hakim, L. (2014). Etnobotani Dan Manajemen Kebunpekarangan Rumah. Jawa Timur : Penerbit Selaras.

Hariana, A. 2007. Tumbuhan Obat dan Khasiatnya. Seri 2. Jakarta: Penebar 
Swadaya.

Rahayu, M. 2006. Pemanfaatan Tumbuhan Obat Secara Tradisional Oleh Masyarakatlokal Di Pulau Wawoni, Sulawesi Tenggara. Bogor : Bidang Botani, Pusat Penelitin Biologi, Lembaga Ilmu Pengetahuan Indonesia (LIPI)

Sinaga, S. 2011. Pengaruh Substitusi Tepung Terigu Dan Jenis Penstabil Dalam Pembuatan Cookies Labu Kuning. Skripsi. Universitas Sumatera Utara. Medan.

Winarto, I.W. (2004). Khasiat dan Manfaat Kunyit. Jakarta: AgroMedia Pustaka. pp 2 -12 .

Zuhud EAM, Haryanto. 1990. Pelestarian Pemanfaatan Tumbuhan Obat di Indonesia, halaman 13-24. Zuhud EAM. 1991. Pelestarian Pemanfaatan Tumbuhan Obat dari Hutan Tropis Indonesia [Prosiding]. Jurusan Konservasi Sumberdaya Hutan Fakultas Kehutanan IPB dan Indonesian Wildlife Fund. Bogor. 